\title{
Removal of Cd(II) ions from aqueous solutions, by adsorption onto Junipers Procera Roots
}

\author{
Khairia Mohammed Al-Ahmary \\ Chemistry Department, Sciences Faculty for Girls, King Abdulaziz University - Jeddah - Kingdom of Saudi Arabia \\ E-mail: khairiaalahmary@yahoo.com
}

\begin{abstract}
This study explored the adsorption behavior of Cd(II) ions on Junipers Procera Roots powder from aqueous solutions. The effect of various operational parameters such as $\mathrm{pH}$, contact time, initial adsorbate concentration, dosage of adsorbent and temperature on adsorption of $\mathrm{Cd}(\mathrm{II})$ ions were investigated using batch adsorption experiments. The optimum $\mathrm{pH}$ for $\mathrm{Cd}$ (II) adsorption was found to be 7.0. The suitability of Langmuir and Freundlich adsorption models to the equilibrium data was investigated. The adsorption was well described by the Freundlich isotherm model indicating the presence of heterogeneous sites for $\mathrm{Cd}(\mathrm{II})$ adsorption. Thermodynamic parameters showed that the adsorption of Cd(II) on Junipers Procera Roots was feasible, spontaneous and exothermic.
\end{abstract}

Keywords: Cd(II), removal, adsorption, Junipers Procera.

\section{Introduction}

The application of adsorption in environmental treatment has become a significant research area in the past ten years. Heavy metal ions are known as priority pollutants, due to their mobility in natural water ecosystems and their toxicity [1-2]. Heavy metals are among the conservative pollutants that are not subject to bacterial attack or other break down or degradation process and are permanent addition to the marine environment [3]. As a result of this, their concentrations often exceed the permissible levels and they can profoundly disrupt biological processes. The discharge of heavy metals into surface waters has become a matter of concern in world over the last two decades. These contaminants are introduced in soil, water ways and sediments through various industrial operations [4]. According to World Health Organization (WHO) the metals of most immediate concern are chromium, copper, zinc, iron, cadmium and lead [5]. Although in nature cadmium occurs in trace amounts and constitutes only $0.00005 \%$ of the crust of the earth, it has been listed by UNEP/WHO as substance dangerous to the environment because along with such metals as lead, mercury, copper, zinc, chromium, tin and silver, it poses a risk of disturbing the balance in ecosystems [6-7]. One characteristic feature of cadmium is its high stability in environment. It is accumulated in soil and living organisms [8-11]. It is easily absorbed by plants, both through their root systems and by leaves, usually in proportion to its concentration in the environment. Acid reaction of soil increases its mobility and availability [12]. Cadmium poses a particular risk to the health of humans and animals because it is easily absorbed, and it remains in tissues for a relatively long time and is accumulated in vital organs, especially in kidneys and liver [13].

Cadmium is used in a number of industries, such as welding and soldering, photography, production of iron, steel and cement and production of nickel-cadmium batteries found in mobile phones and cordless equipment. The amount of cadmium in the environment may also be increased locally by incineration of solid waste. These processes cause pollution of soil and underground and surface water.

The aim of this research is to use abundantly available wild plant Junipers procera for treatment of cadmium wastes. Roots of Junipers procera were used as adsorbent to remove cadmium ions from known concentration of cadmium solutions. The present work deals with some operational parameters of process of adsorption of cadmium ions such as $\mathrm{pH}$, concentration of $\mathrm{Cd}(\mathrm{II})$, temperature, the effect of change in adsorbent mass quantity and effect of contact time on percentage removal of cadmium. 


\section{Experimental}

\subsection{Materials and methods}

All chemicals used were of analytical grade. Cadmium(II) stock solution (1000 mg.L $\mathrm{L}^{-1}$, Merck) was purchased from local suppliers. This was further diluted to get solutions of various known concentrations of cadmium. A temperature controlled variable mechanical shaker at $150 \mathrm{rpm}$ (Thermostat Shaker T-22S, THOMAS SCIENTIFIC CO. LTD. Tokyo Maekawa) was used for batch experiments. The initial $\mathrm{pH}$ values of the solutions were previously adjusted with $\mathrm{HCl}(0.1 \mathrm{M})$ or $\mathrm{NaOH}(0.1 \mathrm{M})$ using METTLER TOLEDO MP230 pH Meter. A vacuum filter assembly having Pyrex filter funnel of porosity grade 4 was used for separating adsorbent from solution. The unknown quantities of Cd(II) were determined by Inductively Coupled Plasma - Atomic Emission Spectrometry (ICP-AES) iCAP-6500 Duo Thermo Scientific United Kingdom. Adsorbent was analyzed by Bruker-Tensor 37 Fourier transform infrared spectrophotometer having spectral range from $7800-400 \mathrm{~cm}^{-1}$. All experiments were performed three times and average values were used in all calculations.

\subsection{Preparation of adsorbent}

Junipers procera roots were collected from local environment of South region of Kingdom of Saudi Arabia in November, 2011. These roots are very versatile natured chemical species as these contain a hydroxyl, carboxylic, carbonyl, amino and nitro groups which are important sites for metal sorption [14, 15]. Fourier transform infrared (FTIR) spectra of Junipers procera roots also indicated the presence of these functional groups (Table 1).

These roots were washed with distilled water to remove any soil or debris. The washed samples were oven dried at a temperature of $70^{\circ} \mathrm{C}$ for two days. Dried roots were ground and sieved to 100 mesh sizes. This powder of adsorbent was stored in air tight glass bottles to protect it from humidity.

\subsection{FT-IR analysis}

The infrared spectra were measured as $\mathrm{KBr}$ discs on Bruker-Tensor 37 Fourier transform infrared spectrophotometer (USA) within range $400-7800 \mathrm{~cm}^{-1}$, evacuated to avoid water and $\mathrm{CO}_{2}$ absorption. $\mathrm{KBr}$ was used as background material in all the analysis. The roots powder $(0.005 \mathrm{~g})$ was mixed with $0.5 \mathrm{KBr}$ and pressed to form a pellet. FTIR spectra of roots before and after adsorption were compared.

\subsection{Recommended procedures}

\subsubsection{Effect of adsorbent dosage}

A preliminary experiment was performed, to determine the most suitable ratio between the Junipers procera roots dose and the solution of cadmium. In $50 \mathrm{ml}$ centrifuge tubes, different weights of each Junipers procera roots samples (50, $100,200,300,400,500 \mathrm{mg}$ ) were accurately weighed and shaken with $50 \mathrm{ml}$ of $100 \mathrm{mg} . \mathrm{L}^{-1} \mathrm{of} \mathrm{CdCl}_{2}$ at $\mathrm{pH}=7 \mathrm{for}$ one hour, then the tubes were centrifuged for 5 minutes at $3000 \mathrm{rpm}, 1 \mathrm{ml}$ sample was taken from the supernatant solution for determination of cadmium concentrations with blank and standard. For each weight triplicate sample were taken and the amount of cadmium remained in the aqueous phase were determined by ICP-AES. The amount of Cd(II) retained on the Junipers procera roots was determined from the difference between the concentrations of $\mathrm{Cd}(\mathrm{II})$ in solution before $\left(C_{o}\right.$ and after $\left(C_{a}\right)$ shaking with the Junipers procera roots. The amount of cadmium retained at equilibrium $q_{e}$, the sorption $(\% E)$ percentage and the distribution ratio $(D)$ of the cadmium uptake onto the used solid sorbent were calculated, respectively employing the equations:

$$
\begin{aligned}
& q_{e}=\frac{\left(C_{o}-C_{a}\right) \times V}{W} \\
& \% E=\frac{\left(C_{o}-C_{a}\right)}{C_{o}} \times 100 \\
& D=\frac{\% E}{100-\% E} \times \frac{V(m L)}{W(g)}
\end{aligned}
$$

where, $V$ is the sample volume in $\mathrm{ml}$ and $W$ is the weight of the Junipers procera roots in grams. The $\% E$ and $D$ values are the average of three independent measurements and the precision in most cases was within $\pm 2 \%$. 


\subsubsection{Effect of temperature on adsorption of $\mathrm{Cd}(\mathrm{II})$}

The $50 \mathrm{~mL}$ volumes of solutions containing $100 \mathrm{mg} . \mathrm{L}^{-1}$ of $\mathrm{CdCl}_{2}$ at $\mathrm{pH}=7$ were adjusted with $500 \mathrm{mg}$ of Junipers procera roots. The mixtures were agitated at $20,25,30,35,40,45^{\circ} \mathrm{C}$. The mixtures were agitated for one hour using a shaking incubation set at $150 \mathrm{rpm}$, centrifuge and the cadmium concentration was measured in supernatant solution using ICP-AES.

\subsubsection{Effect of $\mathbf{p H}$}

A $500 \mathrm{mg}$ of Junipers procera roots sample was accurately weighed in a centrifuge tube to which $50 \mathrm{ml}$ of $100 \mathrm{mg} . \mathrm{L}^{-1}$ $\mathrm{CdCl}_{2}$ solution was added and $\mathrm{pH}$ is adjusted to $\mathrm{pH} 2$ using $\mathrm{HCl}$ and/ or $\mathrm{NaOH}$ shaking for 1 hour, then the tubes were centrifuged and $1 \mathrm{ml}$ sample was taken from the supernatant solution for determination of cadmium concentrations with blank and standard. This procedure was repeated with $\mathrm{pH}(4,7,8,10)$. The amount of ion adsorbed per gram Junipers procera roots and the distribution coefficient $(D)$ were calculated.

\subsubsection{Effect of competing ions}

A $50 \mathrm{ml}$ of $100 \mathrm{mg} . \mathrm{L}^{-1} \mathrm{CdCl}_{2}$ contains $10 \mathrm{mg} . \mathrm{L}^{-1}$ solution of magnesium, zinc and lead as competing ions were added to $500 \mathrm{mg}$ of Junipers procera roots sample in centrifuge tube shaken for 1 hour, centrifuge and the cadmium concentration was measured in supernatant solution using ICP-AES, the procedure was repeated with different concentration 10, 50 and $100 \mathrm{mg} . \mathrm{L}^{-1} \mathrm{MgCl}_{2}, \mathrm{ZnCl}_{2}$ and $\mathrm{PbCl}_{2}$ as competing ions.

\subsubsection{Effect of cadmium concentration}

A $50 \mathrm{ml}$ of different cadmium concentrations from 10 to $100 \mathrm{mg} . \mathrm{L}^{-1}$ at $\mathrm{pH} 7$ was added to $500 \mathrm{mg}$ of Junipers procera roots. Cadmium concentration was measured after 1 hour taken versus reagent blank.

\subsubsection{Effect of contact time}

A $100 \mathrm{ml}$ of $100 \mathrm{mg} \cdot \mathrm{L}^{-1}$ of $\mathrm{CdCl}_{2}$ was transferred to the reaction vessel, which is half liter flat bottomed bottle. An accurate weight of $1.0 \mathrm{~g}$ of the Junipers procera roots sample was transferred to the reaction vessel. At this moment, $\mathrm{t}=$ zero, the experiment has started. Samples of $3 \mathrm{ml}$ from the suspension were taken at different time intervals centrifuge at $3000 \mathrm{rpm}$ for 10 minutes. Two samples $1 \mathrm{ml}$ of each, were taken from the solution for determining cadmium concentrations. These sampling and determination steps were repeated at different time intervals starting from 5 minutes till about 3 hours.

\section{Results and discussion}

\subsection{FT-IR investigations}

The FT-IR spectra before and after adsorption of Cd(II) onto Junipers procera roots was taken. The functional groups before and after adsorption on Junipers procera roots with absorption bands are shown in Table I. The spectra display a number of absorption peaks, indicating the complex nature of chemical compounds of Junipers procera roots. The band shifts in $-\mathrm{OH},-\mathrm{NH}$ and carboxyl groups indicates the involvement of these groups in biosorption of Cd(II) by Junipers procera roots.

Table 1: Difference between adsorption bands $\left(\mathrm{cm}^{-1}\right)$ of Junipers procera roots before and after adsorption of Cd(II) on it.

\begin{tabular}{|c|c|c|c|c|}
\hline \multirow[t]{2}{*}{ IR peak } & \multicolumn{3}{|c|}{ Absorption bands $\left(\mathrm{cm}^{-1}\right)$} & \multirow[t]{2}{*}{ Assignment } \\
\hline & $\begin{array}{l}\text { Before } \\
\text { absorption }\end{array}$ & $\begin{array}{l}\text { After } \\
\text { absorption }\end{array}$ & Differences & \\
\hline 1 & 3410 & 3414 & 4 & Bonded $-\mathrm{OH}$ groups, $-\mathrm{NH}$ stretching \\
\hline 2 & 2932 & 3157 & 225 & Carboxilic acids $-\mathrm{OH}$ stretching \\
\hline 3 & 2358 & 2358 & 0 & - $\mathrm{CH}$ strech \\
\hline 4 & 1739 & 1743 & 4 & $\mathrm{C}=\mathrm{O}$ streching \\
\hline 5 & 1634 & 1636 & 2 & $\mathrm{C}==\mathrm{C}$ strech \\
\hline 6 & 1154 & 1155 & 1 & $\mathrm{C}==\mathrm{C}$ strech \\
\hline 7 & 1034 & 1028 & -6 & R-O strech \\
\hline
\end{tabular}




\subsection{Influence of different parameters on the retention of cadmium ion}

\subsubsection{Effect of Adsorbent Dose:}

Keeping all other parameters constant adsorbent dose was varied from 50 to $500 \mathrm{mg}$, and it was observed that increasing the dose of adsorbent increased the percentage of metal adsorbed as shown in Figure 1 (a). This can be attributed to an increase in surface area of the sorbent, which in turn increases the binding sites. At higher Junipers procera roots dosage, there is a very fast adsorption on to the adsorbent surface that leads to improved uptake of the $\mathrm{Cd}(\mathrm{II})$ ions. However, with increasing Junipers procera roots load, the quantity of Cd(II) adsorbed on to the unit weight of Junipers procera roots gets reduced Fig. 1 (b), thus causing a decrease in $q_{e}$ value with increasing Junipers procera roots loading.

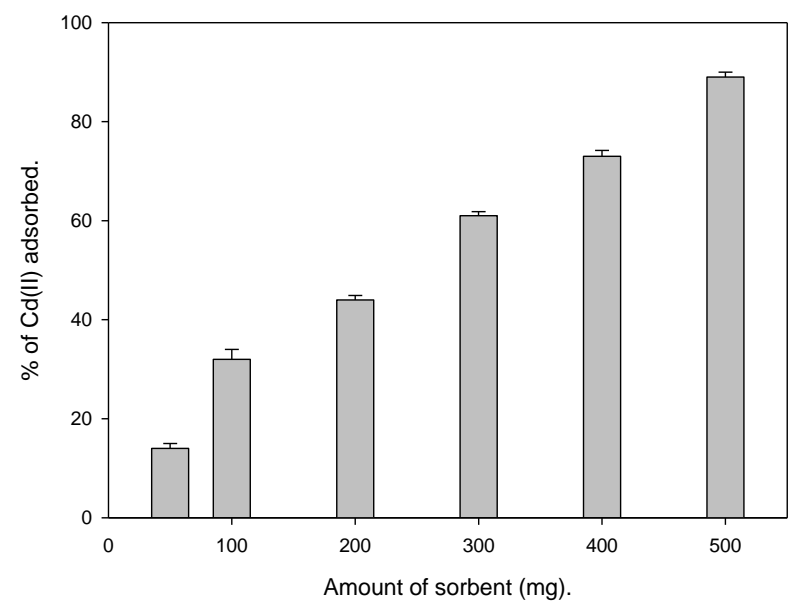

A

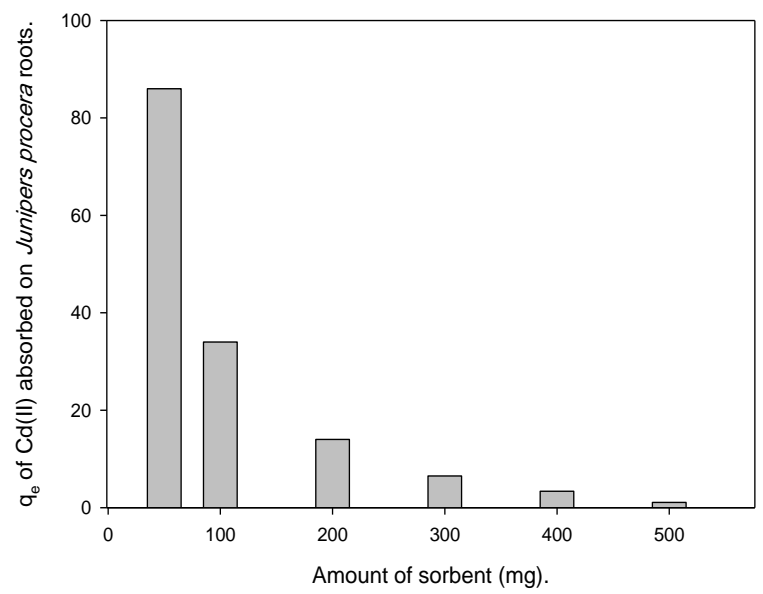

B

Fig. 1: Effect of adsorbent dose on (a) $\% E$ adsorption of $\mathrm{Cd}(\mathrm{II})$, (b) $\mathrm{q}_{\mathrm{e}}$ of adsorbed Cd(II) on Junipers procera roots $\left(\mathrm{V}=50 \mathrm{~mL}, \mathrm{Conc} .=100 \mathrm{mg} . \mathrm{L}^{-1}\right.$, Temp. $=25^{\circ} \mathrm{C}, \mathrm{pH}=7$, Time $=1 \mathrm{~h}$ ).

\subsubsection{Effect of $\mathbf{p H}$}

The influence of the aqueous solution $\mathrm{pH}$ on the distribution ratio $(D)$ of cadmium adsorption by the Junipers procera roots are summarized in Fig 2. It is clear that the $D$ of cadmium adsorbed from the aqueous solution is not significant at low $\mathrm{pH}$ 2-6 due to the competing of $\mathrm{H}^{+}$. At $\mathrm{pH}$ higher than $\mathrm{pH} 6$, the cadmium uptake increased slightly up to $\mathrm{pH} 10$.

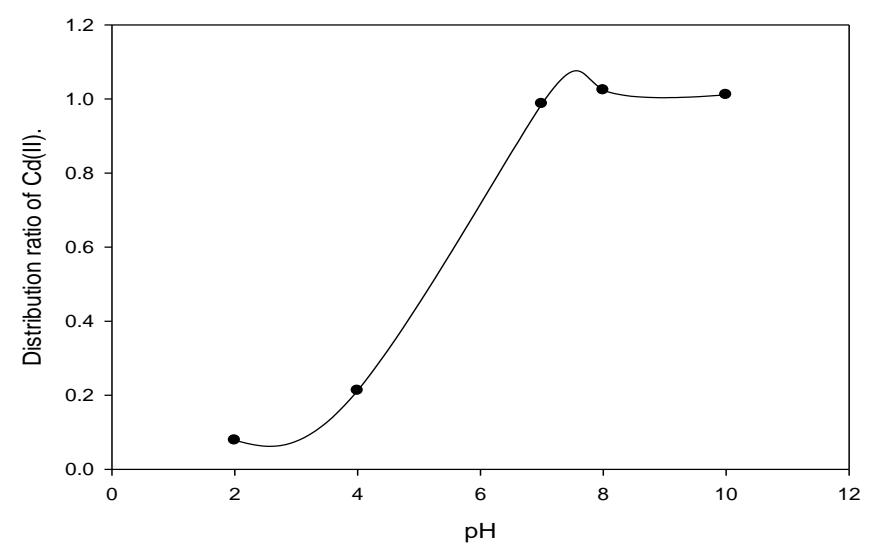

Fig. 2: Effect of $\mathrm{pH}$ on the equilibrium adsorption of $\mathrm{Cd}(\mathrm{II})$ ion on Junipers procera roots $\left(\mathrm{V}=50 \mathrm{~mL}, \mathrm{~W}=500 \mathrm{mg}, \mathrm{Conc} .=100 \mathrm{mg} \cdot \mathrm{L}^{-1}, \mathrm{Temp} .=25^{0} \mathrm{C}\right.$, Time $=1 \mathrm{~h})$.

\subsubsection{Effect of competing ions}

The effect of competitive ions e.g. $\mathrm{Mg}^{2+}, \mathrm{Zn}^{2+}$ and $\mathrm{Pb}^{2+}$ (as one ion or mixture of ions) concentrations on the adsorption of cadmium ions from the aqueous solutions by Junipers procera roots are given in Table 2 . The presence of $\mathrm{Mg}, \mathrm{Zn}$ and $\mathrm{Pb}$ ions decrease the sorption $(\% E$ ) percentage of $\mathrm{Cd}(\mathrm{II})$ by Junipers procera roots and the distribution ratio $(D)$ values. 


\subsubsection{Effect of contact time}

The influence of shaking time on the adsorption percentage of cadmium ions from the aqueous solution by Junipers procera roots was critically examined. The results obtained are shown in Fig 3. The data revealed that the amount, percentage and distribution ratio of cadmium ions adsorbed from the test aqueous solution on the Junipers procera roots increased with increasing the contact time until reached saturation within 2 hours. The curves might be expressed as the sum of two exponential terms and proceeds in two successive steps as follows:

The fast initial uptake was due to accumulation of metal ions on surface of adsorbent which was a rapid step, while more time was consumed on diffusion of ions to binding sites.

Table 2: Influence of competing ions on the cadmium ion uptake by the used solid adsorbents.

\begin{tabular}{|c|c|c|c|c|c|c|c|c|}
\hline \multirow{2}{*}{$\begin{array}{l}\text { Conc. of metal } \\
\left(\mathrm{mg.L}^{-1}\right)\end{array}$} & \multicolumn{2}{|l|}{$\mathrm{Mg}^{2+}$} & \multicolumn{2}{|l|}{$\mathbf{Z n}^{2+}$} & \multicolumn{2}{|l|}{$\mathbf{P b}^{2+}$} & \multicolumn{2}{|c|}{$\mathrm{Mg}^{2+}, \mathrm{Zn}^{2+}, \mathrm{Pb}^{2+}$} \\
\hline & $\% E$ & $D$ & $\% E$ & $D$ & $\% E$ & $D$ & $\% E$ & $D$ \\
\hline 10 & 54 & 0.1174 & 49 & 0.0961 & 58 & 0.1317 & 37 & 0.0769 \\
\hline 50 & 17 & 0.0205 & 13 & 0.0149 & 22 & 0.0251 & 8 & 0.0096 \\
\hline 100 & 10 & 0.0111 & 5 & 0.0053 & 17 & 0.0189 & 2 & 0.0024 \\
\hline
\end{tabular}

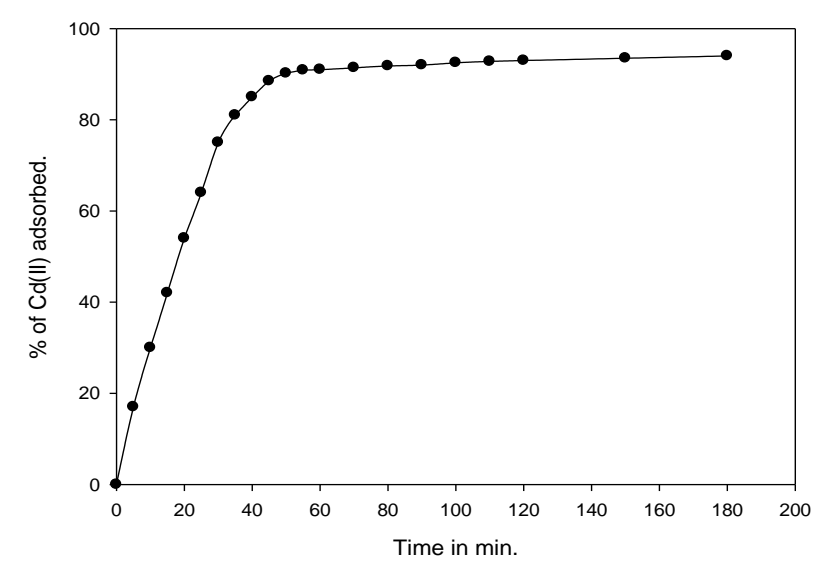

Fig 3: Effect of time on $\% E$ adsorbed cadmium (V=100 mL, W=1 g, Conc. $=100 \mathrm{mg} \cdot \mathrm{L}^{-1}$, Temp. $=25^{\circ} \mathrm{C}, \mathrm{pH}=7$, Time $\left.=3 \mathrm{~h}\right)$.

\subsubsection{Effect of cadmium concentration}

The effect of initial cadmium concentration on the equilibrium uptake capacity and percentage uptake are shown in Fig. 4. It is evident that the amount of $\mathrm{Cd}(\mathrm{II})$ adsorbed at equilibrium increases with increases of $\mathrm{Cd}$ (II) concentration from 10 to $100 \mathrm{mg} \cdot \mathrm{L}^{-1}$. Where a higher initial $\mathrm{Cd}(\mathrm{II})$ concentration provides an important driving force to overcome all resistances of the $\mathrm{Cd}(\mathrm{II})$ between the aqueous and solid phases, thus increasing the rate of sorption that by its rule increase the uptake capacity for sorbent. On the other hand, the percentage uptake shows a decreasing trend as the initial concentration of the $\mathrm{Cd}(\mathrm{II})$ is increased. At lower concentrations, all adsorbate ions present in the adsorption medium could interact with the binding sites, hence higher percentage uptake results. At higher concentrations, because of the saturation of the sorption sites, the percentage uptake of the $\mathrm{Cd}(\mathrm{II})$ ions by Junipers procera roots shows a decreasing trend.

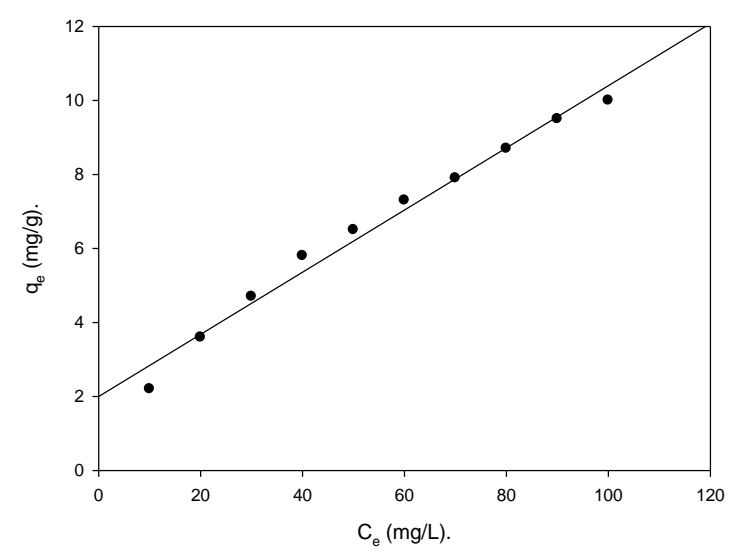

Fig. 4: Effect of concentration on adsorption of Cd(II) on Junipers procera roots. 
The analysis of equilibrium data is basic a requirement for the design of adsorption systems. The experimental data were fitted to the Langmuir and Freundlich equations and the constant parameters of the isotherm equations were calculated.

The Langmuir and Freundlich models were expressed by the

Eqs. (4) and (5), respectively

$$
\begin{aligned}
& \frac{1}{q_{e}}=\frac{1}{Q^{0}}+\frac{1}{b Q^{0} C_{e}} \\
& \ln q_{e}=\ln K_{F}+\frac{1}{n \ln C_{e}}
\end{aligned}
$$

where $Q^{o}$ (mg. $\left.\mathrm{g}^{-1}\right)$ is the maximum adsorption capacity and $b\left(\mathrm{~L}_{\mathrm{mg}} \mathrm{m}^{-1}\right)$ is the binding constant which is related to the heat of adsorption. $K_{F}\left(\mathrm{~L} . \mathrm{g}^{-1}\right)$ and $1 / n$ are the Freundlich constants.

The linearized Freundlich and Langmuir plots are given in Figures 5 and 6. The slopes of the linearized Freundlich and Langmuir plots were used to calculate the adsorption constants presented in Table 3. The value of correlation coefficient for Freundlich equation $\left(R^{2}=0.9984\right)$ is higher than Langmuir $\left(R^{2}=0.9948\right)$ suggesting that equilibrium data are well described by Freundlich isotherm. Furthermore, the Freundlich exponent $1 / n$ gives an indication of the favorability of adsorption. The value of $1 / n<1.0$ represents a favorable adsorption condition $(16,17)$. The value of $1 / n$ obtained in the present study for Cd(II) is less than unity, indicating the favorable adsorption of metal ions on Junipers procera roots.

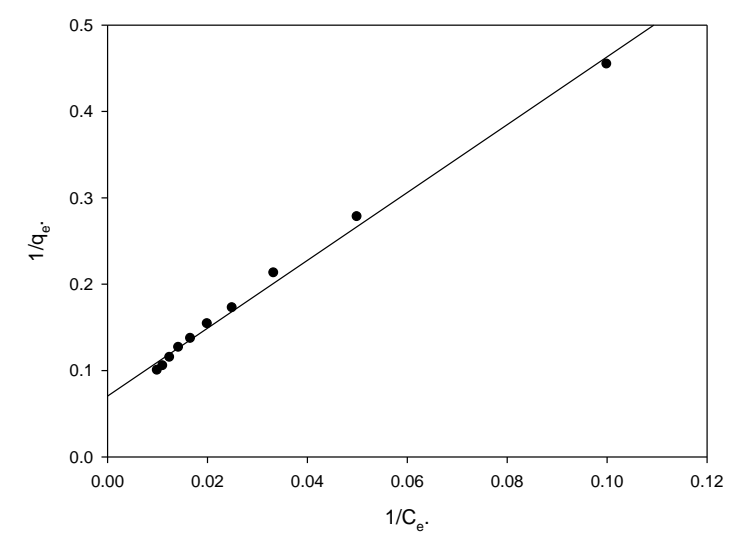

Fig. 5: Langmuir adsorption isotherm for $\mathrm{Cd}(\mathrm{II})$ on Junipers procera roots.

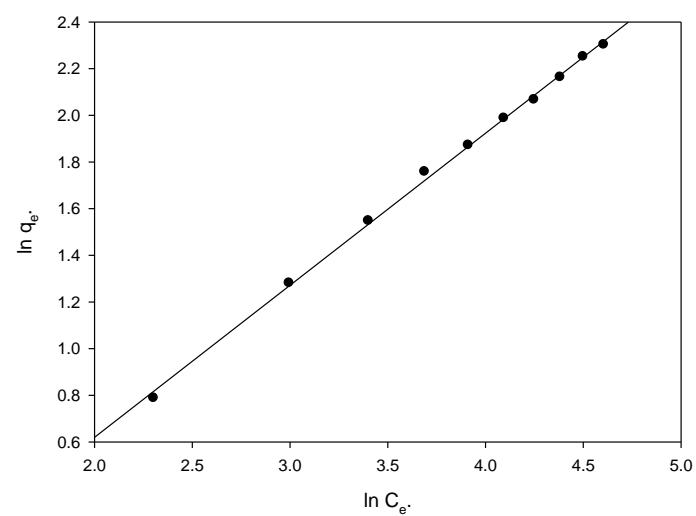

Fig. 6: Freundlich adsorption isotherm for $\mathrm{Cd}(\mathrm{II})$ on Junipers procera roots.

Table 3: Langmuir and Freundlich isotherm parameters for the adsorption of Cd(II) on Junipers procera roots.

\begin{tabular}{llllll}
\hline $\begin{array}{l}\text { Langmuir model } \\
\boldsymbol{Q}^{\boldsymbol{o}}\left(\mathbf{m g . g}^{\mathbf{- 1}}\right)\end{array}$ & $\boldsymbol{b}\left(\mathbf{L . m g}^{-\mathbf{1}}\right)$ & $\mathbf{R}^{\mathbf{2}}$ & \multicolumn{2}{l}{ Freundlich model } \\
\hline 14.1985 & 0.2545 & 0.9948 & $\boldsymbol{K}_{\boldsymbol{F}}\left(\mathbf{L . g} \mathbf{g}^{-\mathbf{1}}\right)$ & $\mathbf{1 / n}$ & $\mathbf{R}^{\mathbf{2}}$ \\
\hline
\end{tabular}




\subsubsection{Effect of temperature}

The effect of temperature on the adsorption capacity of $\mathrm{Cd}(\mathrm{II})$ ions was studied at $20,25,30,35,40$, and $45^{\circ} \mathrm{C}$ and the results were shown in Fig. 7. The results show that the adsorption capacity increased from 6.88 to 13.24 mg. $\mathrm{g}^{-1}$ with increases of temperatures from 293 to $318 \mathrm{~K}$, indicating that the adsorption was endothermic in nature. The rise in adsorption capacity was due to the increase in collision frequency between adsorbent and $\mathrm{Cd}(\mathrm{II})$ ions.

Thermodynamic parameters like standard free energy change $\left(\Delta G^{\circ}\right)$, enthalpy change $\left(\Delta H^{\circ}\right)$, and entropy change $\left(\Delta S^{\circ}\right)$ were estimated to evaluate the feasibility of the adsorption process by the following equations:

$\Delta G^{o}=-R T \ln K_{C}$

$\ln K_{C}=\left(\frac{\Delta S^{o}}{R}\right)-\left(\frac{\Delta H^{o}}{R T}\right)$

where $K_{c}$ is the distribution coefficient for the adsorption, $R$ is the universal gas constant $\left(8.314 \mathrm{~J} \cdot \mathrm{mol}^{-1} \cdot \mathrm{K}^{-1}\right)$ and $T$ is the absolute temperature (K). The negative $\Delta G^{\circ}$ values $1.596,2.048,2.295,2.36,2.631$ and $3.578 \mathrm{~kJ} \mathrm{~mol}^{-1}$ for $20,25,30$, 35,40 , and $45^{\circ} \mathrm{C}$, respectively, increased with temperature, indicating the feasibility and spontaneity of adsorption process of $\mathrm{Cd}(\mathrm{II})$ ions on Junipers procera roots. The positive value of $\Delta H^{\circ}\left(16.524 \mathrm{~kJ}^{\mathrm{mol}}{ }^{-1}\right)$ confirmed the $^{-1}$ endothermic nature of adsorption process, while the positive value of $\Delta S^{\circ}\left(0.0725 \mathrm{~kJ} . \mathrm{mol}^{-1} \mathrm{~K}^{-1}\right)$ revealed the increase in randomness at the solid/solution interface during the adsorption process $(17,18)$.

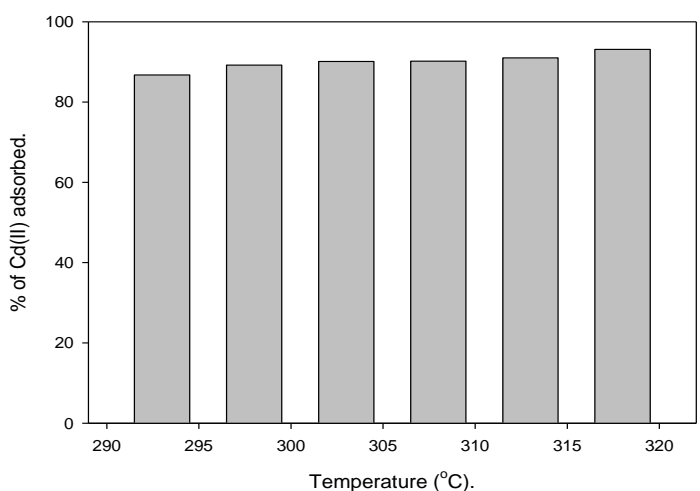

Fig. 7: Effect of Temperature on $\% E$ adsorption of $\mathrm{Cd}(\mathrm{II})$ on Junipers procera roots $\left(\mathrm{V}=50 \mathrm{~mL}, \mathrm{~W}=500 \mathrm{mg}\right.$, Conc. $=100 \mathrm{mg} . \mathrm{L}^{-1}, \mathrm{pH}=7$, Time $=1 \mathrm{~h}$ ).

\section{Conclusion}

In this work, Junipers procera roots powder was used as a cost effective adsorbent for removal of cadmium(II) ions from solution. Batch adsorption studies show that removal is dependent upon process parameters such as $\mathrm{pH}$, dosage of Junipers procera roots, concentration of Cd(II) ions and contact time. The equilibrium data fitted well to Freundlich isotherm which suggests heterogeneity in the adsorption sites. Thermodynamic parameters suggested that the adsorption process was spontaneous and governed by physisorption interaction.

\section{References}

[1] B. Volesky, Advances in Biosorption of Metals, Sselection of Biomass Types. FEMS Microbiology Reviews. 14 (1994) $291-302$.

[2] B. Volesky, Z.R. Holan, Biosorption of Heavy Metals, Biotechnology Progress, May-June, 11(3) (1995) $235-250$.

[3] F.E. El-Nady, M.M. Atta, Toxicity and Bioaccumulation of Heavy Metals to Some Marine Biota From the Egyptain Coastal Wasters. J. Environ. Sci. Health. A 31 (1996) 1529-1545.

[4] D. Kratochvil, B. Volesky, Advances in the Biosorption of Heavy Metals. Trends in Biotechnology. Trends Biotechnol. 16 (1998) 291-300.

[5] WHO, World Health Organiztion, report, Guidelines for drinking water quality, Geneva, (1984).

[6] B. Jankiewicz, B. Ptaszynski, A. Turek, Spectrophotometric Determination of Iron (II) in the Soil of Selected Allotment Gardens in Lodz, Polish Journal of Environmental Studies, 11(6) (2002) 745-749.

[7] M.M. Antonijevic, M. Maric, Determination of the Content of Heavy Metals in Pyrite Contaminated Soil and Plants, Sensors, 8 (2008) 58575865.

[8] H. Kowalska-Pylka, A. Kot, J. Wiercinski, K. Kursa, G. Walkuska, W. Cybulski, Lead, cadmium, copper and zinc content in vegetables, gooseberry fruit and soil from gardening plots of Lublin. Rocz. PZH. 46 (1995) 3-12. 
[9] B. Jankiewicz, B. Ptaszynski, A. Turek, Spectrophotometric Determination of Copper (II) in the Soil of Selected Allotment Gardens in Lodz, Polish Journal of Environmental Studies, 8(1) (1999) 35-38.

[10] F. Yilmaze, M. Isiliglum, M. Merdivan, Heavy metals levels in some macrofungi, Turk J. Bot. 27, (2003) 45-56.

[11] B.N. Ita, J.P. Essien, G.A. EBONG, Heavy metal levels in fruiting bodies of edible and non-edible mushrooms from the Niger Delta Region of Nigeria, J. Agric. \& Soc. Scien., (2006) 84-87.

[12] A. Kabata - Pendias, Biogeochemia pierwiastkow sladowych, Wyd. Geologiczne, Warszawa, (1993).

[13] B. Jankiewicz, B. Ptaszyński, M. Wieczorek, Spectrophotometric Determination of Cadmium (II) in Soil of Allotment Gardens in Łódź, Polish Journal of Environmental Studies, 9(2) (2000) 83-86.

[14] B. Volesky, Biosorption process simulation tools, Hydrometallurgy, 71(1-2) (2003) 179-190.

[15] S. Sai Subhashini, S. Kaliappan, M. Velan, Removal of heavy metal from aqueous solution using Schizosaccharomyces pombe in free and alginate immobilized cells. International Conference on Environmental Science and Technology, 6 (2011) 107-111.

[16] V.K. Gupta, D. Mohan, S. Sharma, K.T. Park, Removal of chromium(VI) from electroplating industry wastewater using bagasse fly ash - a sugar industry waste material. Environmentalist, 19 (1999) 129-136.

[17] K. Rajeev, H. Shaziya, Adsorption of $\mathrm{Cu} 2+$ from aqueous solution onto iron oxide coated eggshell powder: Evaluation of equilibrium, isotherms, kinetics, and regeneration capacity Rais Ahmad, Arabian Journal of Chemistry, 5(3) (2012) 353-359.

[18] V.K. Gupta, I. Ali, Utilization of bagasse fly ash (a sugar industry waste) for the removal of copper and zinc from wastewater. Sep. Purif. Technol. 18 (2000) 131-140. 